\title{
PENGARUH GCG TERHADAP KINERJA PENGELOLAAN DANA DESA DENGAN MODERASI SISTEM PENGENDALIAN INTERNAL
}

\author{
Yuli Budiati \\ yulibudiati75@gmail.com \\ Eviatiwi Kusumaningtyas Sugiyanto \\ Asih Niati \\ Universitas Semarang
}

\begin{abstract}
Village funds (dana desa) must be utilized and used for the benefit of village community and their implementation begins together with financial reports to be accountable. There are very few village government official in providing village fund management reports, and request information about village financial assistance. Related research to analyze the perceptions of the village government based on the principles of Good Governance with dimensions, accountability and participation and the capacity of the village apparatus on the performance of village fund management with an internal control system as a moderating variable. Research conducted in Karangawen Subdistrict, Demak Regency on parties involved in village government funds, namely the village head, village secretary, treasurer, executor of development activities, executor of midterm activities, head of the activity management team and family welfare driving team, in 12 villages with 84 respondents. The analytical tool used in this study is SEM with WrapPLS. The results showed that transparency, accountability, participation and apparatus capacity had a significant positive effect on the performance of village fund management. While the internal control system failed to become a variable of moderation, planning, accountability, participation in village financial support.
\end{abstract}

Key words: GCG; performance; internal control.

\begin{abstract}
ABSTRAK
Dana desa harus dimanfaatkan dan digunakan untuk kepentingan desa dan pelaksanaannya diawasi bersama serta dilengkapi dengan laporan-laporan secara tertulis agar dapat dipertanggungjawabkan. Masih sangat sedikit aparatur pemerintah desa dalam memberikan laporan pengelolaan dana desa, sehingga memunculkan pertanyaan mengenai bagaimana kinerja pengelolaan dana desa. Penelitian bermaksud untuk menganalisis persepsi dari aparatur pemerintah desa berdasarkan prinsip Good Governance dengan dimensi transparansi, akuntabilitas dan partisipasi dan kapasitas aparatur desa terhadap kinerja pengeloaan dana desa dengan sistem pengendalian internal sebagai variabel moderating. Penelitian dilakukan di Kecamatan Karangawen Kabupaten Demak pada pihak yang terlibat dalam pengelolaan dana desa yaitu kepala desa, sekretaris desa, bendahara, pelaksana kegiatan pembangunan, pelaksana kegiatan pemerintahan, ketua tim pengelola kegiatan dan tim penggerak kesejahterahteraan keluarga, pada 12 desa dengan jumlah responden 84 orang. Alat analisis yang digunakan dalam penelitian ini adalah SEM dengan WrapPLS. Hasil penelitian menunjukkan bahwa transaparansi, akuntabilitas, partisipasi dan kapasitas aparatur berpengaruh positif signifikan terhadap kinerja pengelolaan dana desa. Sedangkan sistem pengendalian internal gagal menjadi variabel moderasi pengaruh transparansi, akuntabilitas, partisipasi terhadap kinerja pengelolaan keuangan desa.
\end{abstract}

Kata kunci: GCG; kinerja; pengendalian internal.

\section{PENDAHULUAN}

Undang-Undang Nomor 6 Tahun 2014 tentang Desa membawa berkah tersendiri pasalnya desa mendapatkan alokasi dana yang jumlahnya cukup besar untuk pembangunan, yaitu yang bersumber dari Dana 
Desa. UU memberikan amanat dan kewenangan kepada desa untuk mengelola dana yang tidak kecil dengan harapan agar dapat dilakukan percepatan pembangunan dengan mengandalkan potensi-potensi lokal setempat (Atiq, 2018). Pendapatan asli desa sendiri terdiri dari hasil usaha, hasil aset, swadaya, partisipasi, gotong royong, dan lain-lain (Rustiarini, 2016). Pendapatan desa yang besar dari beberapa sumber tersebut harus dikelola secara benar dan transparan, untuk itu aparatur desa sebagai aktor dari pengelolaan dana desa dituntut untuk memiliki pemahaman yang baik tentang tata cara dan tata kelola keuangan.

Tata cara dan tata kelola pemerintahan yang baik tercermin dalam prinsip-prinsip good governance. Dalam UU desa dan peraturan terkait lainnya tegas disebutkan bahwa pengelolaan keuangan desa harus transparan, akuntabel, partisipasif, tertib dan disiplin (Soleh, et al., 2016). Prinsip pengelolaan yang baik harus memiliki prinsip transparansi, keterbukaan, akuntabilitas, partisipasi, keadilan dan kemandirian (Sari, 2013). Sedangkan sebagai praktik pelayanan publik yang baik harus memuat prinsipprinsip efisiensi, keadilan, transparansi, dan akuntabilitas (Rahadian, 2008). Selanjutnya persyaratan minimal untuk mencapai good governance dalam mengelola keuangan daerah adalah adanya transparansi, akuntabilitas, partisipasi, penegakan hukum, efektifitas dan efisien, dan keadilan (Pazri, 2016).

Tahun 2018 Pemkab Demak mengalokasikan Alokasi Dana Desa (ADD) sebesar Rp. 229,5 Miliar sebagai upaya untuk mendukung pengembangan potensi desa yang selama ini terkendala faktor pembiayaan. Sebagai bentuk dari implementasi good governance terkait pengelolaan dana desa, Kabupaten Demak meluncurkan aplikasi Desa Waskita, hal tersebut menjadi yang pertama di Jawa Tengah dan di Indonesia. Melalui portal www.apbdes. inspektoratdmk.co.id tersebut semua pelaporan pengeloaan dana desa untuk desadesa di Kabupaten Demak dapat dipantau langsung oleh publik (Kurniawan, 2018).
Desa yang memiliki pelaporan keuangan yang bagus akan mendapat opini Desa Waskita Tanpa Cidra atau desa mandiri tanpa penyimpangan. Salah satu tujuan dari aplikasi ini adalah agar terbentuk desa mandiri yaitu pemerintahan desa yang mengedepankan transparansi, akuntabel, dan partisipasif (Kurniawan, 2018).

Desa-desa di Kabupaten Demak mempunyai wewenang penuh dalam mengelola keuangan desa. Karangawen merupakan salah satu kecamatan di Kabupaten Demak yang menerima ADD sebesar Rp. 6.308.477. 000 di tahun 2018. Kecamatan Karangawen terdiri dari 12 desa yaitu Jragung, Wonosekar, Margohayu, Teluk, Tlogorejo, Rejosari, Karangawen, Kuripan, Bumirejo, Bram- bang, Sidorejo, Pundenarum. Salah satu bentuk dari alokasi dana desa yang dilaksanakan di Kecamatan Karangawen adalah pembangunan infrastruktur seperti pembuatan jembatan, betonisasi, talud. Selain itu dana desa dapat dialokasikan untuk mendukung kegiatan yang bertujuan untuk menurunkan angka kemiskinan. Upaya yang dilakukan Pemdes Karangawen sebagai cerminan pelaksanaan good governance tahun sebelumnya adalah melaksanakan rapat koordinasi pembahasan ADD (Alokasi Dana Desa) dan DD (Dana Desa) yang dilaksanakan di Aula Kantor Pertemuan Desa Tlogorejo Kecamatan Karangawen Kab. Demak. Rakor tersebut bertujuan agar seluruh elemen masyarakat sama-sama mengetahui pemanfaatan dan penggunaan anggaran selama tahun 2018. Dana Desa harus dimanfaatkan dan digunakan untuk kepentingan Desa dan pelaksanaannya diawasi bersama serta dilengkapi dengan laporan-laporan secara tertulis agar dapat dipertanggungjawabkan. Jika masyarakat menemukan kejanggalan dapat langsung ditanyakan kepada Kelapa Desa atau BPD. Hal-hal tersebut merupakan bentuk implementasi dari prinsip good governance yaitu transparansi, akuntanbilitas dan partisipasi. Aparatur desa sebagai aktor dalam pengelola dana desa sangat menentukan keberhasilan program-program 
pembangunan desa. Kapasitas dari SDM dalam hal ini aparatur desa sangat menentukan kinerja pengelolaan dana desa. Kapasitas merupakan suatu kemampuan yang dimiliki oleh individu suatu organisasi atau suatu sistem dalam melaksanakan fungsi-fungsinya secara efektif, efisien, dan berkelanjutan sesuai dengan aturan yang berlaku untuk mencapai tujuan bersama dalam pembangunan (Munti dan Fahlevi, 2017). Sampai saat ini belum ada standar yang dapat diterapkan diseluruh Indonesia terkait kualitas aparatur yang kompeten dalam mengelola dana desa. Sehingga pemerintah desa memiliki kinerja yang berbeda-beda dalam mengelola dana desa.

Ada tidaknya pengawasan dalam hal ini sistem pengendalian internal juga akan memperbesar pengaruhnya terhadap kinerja perangkat desa (Tarjono dan Nugraha, 2015). Sistem pengendalian intern merupakan prasyarat bagi penyelenggaraan pemerintahan dan pengelolaan keuangan negara yang amanah. Karena dengan Sistem Pengendalian Intern yang baik maka suatu organisasi akan dapat berjalan dengan baik (Hamsinar, 2017). Dalam struktur organisasi pemerintah Indonesia, fungsi pengawasan internal dalam arti luas diselenggarakan oleh Badan Pengawas Keuangan dan Pembangunan (BPKP) dan Inspektorat Jendral Pembangunan (Halidayati, 2014). Dengan adanya sistem pengendalian internal prinsip-prinsip good governance dapat diajalankan dengan baik. Untuk itu berdasarkan penjelasan sebelumnya, selain prinsipprinsip good governance dan kapasitas aparatur desa menjadi hal yang utama dalam penentu kinerja, sistem pengendalian internal juga memperkuat keberhasilan pengelolaan dana desa.

Dalam penelitian ini perumusan masalah yang diangkat adalah bagaimana persepsi aparatur pemerintah desa dan kapasitas aparatur pemerintah desa terhadap kinerja pengelolaan dana desa dengan sistem pengendalian internal sebagai variabel moderasi di Kecamatan Karangawen Kabupaten Demak. Penelitian ini bertujuan untuk menganalisis persepsi good corporate gover-nance dari aparatur pemerintah desa dan kapasitas aparatur desa terhadap kinerja pengeloaan dana desa dengan sistem pengendalian internal sebagai variabel moderasi.

\section{TINJAUAN TEORETIS}

\section{Transparansi dan Kinerja Pengelolaan Dana Desa}

Transparansi merupakan salah satu prinsip dari good governance. Transparansi dibangun di atas dasar arus informasi yang bebas, seluruh proses pemerintahan, lembaga-lembaga dan informasi perlu diakses oleh pihak-pihak yang berkepentingan, dan informasi yang tersedia harus memadai agar dapat dimengerti dan dipantau (Coryanata, 2007).

Danin (2005) mendefinisikan transparansi sebagai keterbukaan informasi, baik dalam proses pengambilan keputusan maupun dalam mengungkapkan informasi material dan relevan. Hal ini sejalan dengan penelitian Risya Umami dan Idang Nurodin (2017) yang menyatakan bahwa transparansi dapat memberikan jaminan akses informasi yang terbuka kepada semua orang dan masyarakat untuk memperoleh informasi keuangan maupun kebijakan yang diambil oleh pemerintah. Selanjutnya, dijelaskan bahwa prinsip transparansi dalam pengelolaan keuangan dapat dilaksanakan melalui sosialisasi kepada masyarakat disetiap pencairan dana dari pendapatan tranfer, pemasangan baliho tentang Laporan Pertanggungjawaban dari Realisasi Anggaran Pendapatan dan Belanja Desa. Transparansi yakni adanya kebijakan terbuka bagi pengawasan. Transparansi merupakan prinsip dimana menjamin akses atau kebebasan bagi setiap orang untuk mendapatkan informasi tentang organisasi tersebut. Transparansi berpengaruh terhadap kinerja organisasi, dikarenakan sebuah transparansi merupakan suatu alat yang digunakan oleh agent untuk menunjukan bahwa harapan atau tujuan yang diinginkan oleh principal telah dipubli- 
kasikan. Hal ini akan mempengaruhi kinerja dari organisasi tersebut.

$\mathrm{H}_{1}$ : Transparansi Berpengaruh terhadap Kinerja Pengelolaan Dana Desa

\section{Akuntabilitas dan Kinerja Pengelolaan Dana Desa}

Mardiasmo (2012) mendefinisikan akuntabilitas merupakan sebuah kewajiban untuk melaporkan dan mempertanggungjawabkan atas keberhasilan ataupun kegagalan pelaksanaan misi organisasi dalam mencapai hasil yang telah ditetapkan sebelumnya, melalui media pertanggungjawaban yang dikerjakan secara berkala. Sedangkan, Danin (2005) mendefinisikan akuntabilitas sebagai kejelasan fungsi, struktur, sistem, dan pertanggungjawaban organ perusahaan sehingga pengelolaan perusahaan terlaksana secara efektif. Ahdiyana (2008) menyimpulkan jika akuntabilitas berhubungan dengan kewajiban dari institusi atau aparat yang bekerja di dalamnya untuk membuat kebijakan atau melakukan tindakan yang sesuai dengan nilai yang berlaku maupun kebutuhan masyarakat. Akuntabilitas publik menuntut adanya pembatasan tugas yang jelas dan efisien dari para aparat. Risya Umami dan Idang Nurodin (2017) juga menyebutkan akuntabilitas merupakan pertanggungjawaban oleh lembaga yang diberi wewenang dalam mengelola sumber daya publik. Akuntabilitas berpengaruh terhadap kinerja organisasi dikarenakan, akuntabilitas adalah bentuk pertanggungjawaban dari agent kepada principal. Mardiasmo (2012) mendefinisikan bahwa akuntabilitas publik merupakan kewajiban pihak pemegang amanah (agent) untuk memberikan pertanggungjawaban, dan mengungkapkan segala aktivitas dan kegiatan yang menjadi tanggung jawabnya kepada pihak pemberi amanah (principal) yang memiliki hak dan kewenangan untuk meminta pertanggungjawaban tersebut. Kesuksesan kinerja organisasi ditentukan dari keselarasan antara agent dan principal, akuntabilitas yang baik dalam organisasi akan mengurangi konflik yang terjadi. Sehingga akuntablitas berpengaruh terhadap kesuksesan dari organisasi tersebut. Kesuksesan dari organisasi dapat dilihat dari kinerja yang baik, hal ini juga didukung oleh penelitian Risya Umami dan Idang Nurodin (2017) dan Gayatri, Made Yeni Latrini, Ni Luh Sari Widhiyani (2017) sehingga hipotesis yang dikembangkan adalah:

$\mathrm{H}_{2}$ : Akuntabilitas Berpengaruh terhadap Kinerja Pengelolaan DanaDesa

\section{Partisipasi dan Kinerja Pengelolaan Dana Desa}

Partisipasi banyak menguntungkan bagi suatu organisasi. Melalui partisipasi masyarakat, organisasi dapat membuat suatu akuntabilitas organisasi tersebut semakin baik. Dalam sektor publik ataupun pemerintahan, partisipasi masyarakat berperan penting. Cornyata (2007) menyebutkan bahwa partisipasi masyarakat mempunyai peranan penting dalam otonomi daerah karena dalam partisipasi terdapat aspek pengawasan dan aspirasi. Rita et al. (2011) menyebutkan bahwa partisipasi adalah prinsip bahwa setiap orang memiliki hak untuk terlibat dalam pengambilan keputusan di setiap kegiatan penyelenggaraan pemerintahan. Keterlibatan dalam pengambilan keputusan dapat dilakukan secara langsung atau secara tidak langsung. Partisipasi adalah prinsip bahwa setiap orang memiliki hak untuk terlibat dalam pengambilan keputusan di setiap kegiatan penyelenggaraan pemerintah. Partisipatif berarti bahwa setiap orang, siapa saja dapat turut serta dalam pengambilan keputusan. Partisipasi berpengaruh terhadap kinerja perangkat desa. Dalam pengelolaan dana desa partisipasi masyarakat dibutuhkan untuk membuat suatu keputusan. Untuk menjalankan suatu akuntabilitas, partisipasi masyarakat dibutuhkan dalam penyusunan juga pengawasan terhadap organisasi. Hal ini dapat membuat tujuan antara agent dan principal berjalan lurus dan terhindar dari konflik. Cornyata (2007) menyebutkan bahwa partisipasi masyarakat mempunyai 
peranan penting dalam otonomi daerah karena dalam partisipasi terdapat aspek pengawasan dan aspirasi.

$\mathrm{H}_{3}$ : Partisipasi Berpengaruh terhadap Kinerja Pengelolaan Dana Desa

\section{Kapasitas Aparatur Desa dan Kinerja Pengelolaan Dana Desa}

Kapasitas dapat didefinisikan sebagai kemampuan manusia, lembaga dan masyarakat untuk melakukan keberhasilan, untuk mengidentifikasi dan mencapai tujuan mereka, dan untuk mengubah bila diperlukan untuk tujuan keberlanjutan, pengembangan dan kemajuan (Mouallem dan Analoui, 2014).

Selanjutnya, kapasitas adalah pemahaman, sikap, kemampuan, keterampilan, nilai-nilai, hubungan, perilaku, sumber daya, motivasi dan kondisi-kondisi yang memberikan kemungkinan bagi setiap sistem, jaringan kerja, organisasi, dan individu untuk menerapkan fungsi-fungsi mereka dan mencapai tujuan pembangunan yang telah ditetapkan antar waktu. Dalam konteks pengelolaan keuangan, aparatur yang memiliki kapasitas berupa kompetensi akuntansi yang baik sehingga mampu memahami logika akuntansi yang menjadi dasar dalam pengelolaan keuangan yang professional (Rafar, Fahlevi, dan Basri, 2015). Tjiptoherianto (2010) menjelaskan kinerja dan kualitas kapasitas sumber daya manusia dalam melaksanakan suatu fungsi, termasuk akuntansi, dapat dilihat dari level of responsibility dan kompetensi sumber daya tersebut.

Islami (2016) menyatakan kapasitas merupakan suatau kemampuan yang dimiliki oleh individu suatu organisasi atau suatu sistem dalam melaksanakan fungsifungsinya secara efektif, efisien, dan berkelanjutan sesuai dengan aturan yang berlaku untuk mencapai tujuan bersama dalam pembangunan.

Hal ini juga sejalan dengan penelitian yang dilakukan oleh Finta Munti dan Heru Fahlevi (2017), maka hipotesis yang dirumuskan adalah:
$\mathrm{H}_{4}$ : Kapasitas Aparatur Desa Berpengaruh terhadap Kinerja Pengelolaan Dana Desa

\section{Sistem Pengendalian Internal Memoderasi Hubungan Transparansi dengan Kinerja Pengelolaan Dana Desa}

Peran Sistem Pengendalian Intern adalah untuk meningkatkan kinerja, transparansi, dan akuntabilitas pengelolaan keuangan Negara (Hamsinar, 2017). Melalui transparansi penyelenggaraan pemerintah, masyarakat diberikan kesempatan untuk mengetahui apa yang akan terjadi dalam pemerintahan, termasuk diantaranya kebijakan yang akan atau telah diambil oleh pemerintah, serta implementasi kebijakan tesebut. Pengawasan dari masyarakat dapat mencegah terjadinya mis-alokasi sumber daya maupun berbagai pelanggaran dalam kegiatan pemerintah seperti korupsi, (Kusuma, 2012).

$\mathrm{H}_{5}$ : Sistem Pengendalian Internal Memperkuat Pengaruh Transparansi terhadap Kinerja Pengelolaan Dana Desa

\section{Sistem Pengendalian Internal Memoderasi Hubungan Akuntabilitas dengan Kinerja Pengelolaan Dana Desa}

Akuntabilitas publik akan tercapai jika pengawasan yang dilakukan oleh dewan dan masyarakat berjalan secara efektif dan mewujudkan good governance (Kurniawan A., 2012). Peraturan Pemerintah Nomor 60 tahun 2008 tentang sistem pengendalian intern pemerintah, dinyatakan bahwa untuk mencapai pengelolaan keuangan negara yang efisien, efektif, transparan, dan akuntabel, wajib melakukan pengendalian atas penyelenggaraan atas kegiatan pemerintah. Sistem pengendalian intern pemerintah memiliki fungsi untuk memberi keyakinan yang memadai bagi terciptanya efektivitas dan efisiensi pencapaian tujuan penyelenggaraan pemerintah negara, keandalan laporan keuangan, pengamanan aset negara dan ketaatan terhadap undang-undang, pengawasan internal dapat memoderasi akuntabilitas terhadap kinerja aparat. Pe- 
ngawasan internal dapat memoderasi akuntabilitas terhadap kinerja aparat pemerintah daerah (Ernawilis, 2015)

$\mathrm{H}_{6}$ : Sistem Pengendalian Internal Memperkuat Pengaruh Akuntabilitas terhadap Kinerja Pengelolaan Dana Desa

\section{Sistem Pengendalian Internal Memoderasi Hubungan Partisipasi dengan Kinerja Pengelolaan Dana Desa}

Partisipasi masyarakat merupakan kunci sukses dari pelaksanaan otonomi daerah karena dalam partisipasi menyangkut aspek pengawasan dan aspirasi (Hamsinar, 2017). Sistem pengendalian intern merupakan prasyarat bagi penyelenggaraan pemerintahan dan pengelolaan keuangan negara yang amanah. Karena dengan Sistem Pengendalian Intern yang baik maka suatu organisasi akan dapat berjalan dengan baik. Pengawasan merupakan tahap integral dengan keseluruhan tahap pada penyusunan dan pelaporan APBD. Dengan adanya pengawasan di setiap tahapan pengelolaan keuangan daerah akan memperbesar pengaruhnya pada kinerja pengelolaan keuangan daerah (Primadana, Yuniarta, dan Adiputra, 2014). Pengawasan internal dapat memoderasi partisipasi anggaran terhadap kinerja organisasi (Tarjono dan Nugraha, 2015).

$\mathrm{H}_{7}$ : Sistem Pengendalian Internal Memperkuat Pengaruh Partisipasi terhadap Kinerja Pengelolaan Dana Desa

\section{METODE PENELITIAN}

\section{Jenis Penelitian}

Berdasarkan pada derajat kristalisasi pertanyaan penelitian, maka penelitian ini termasuk dalam formal study yang dimulai dengan suatu hipotesis atau pertanyaan penelitian yang kemudian melibatkan prosedur dan spesifikasi sumber data yang sesuai, yang bertujuan untuk menguji hipotesis atau jawaban atas pertanyaan penelitian yang diajukan (Cooper dan Shindler, 2014), data dikumpulkan menggunakan kuesioner. Penelitian ini bersifat menguji pengaruh dan hubungan antar dua variabel atau lebih, serta bagaimana satu variabel menghasilkan perubahan pada variabel lain, sehingga penelitian ini termasuk causal-explanatory study.

Dari perspektif dimensi waktu, penelitian ini termasuk cross-sectional study karena penelitian dilakukan satu kali pada satu waktu tertentu. Lingkup studi penelitian ini adalah statistical study. Menurut (Cooper dan Shindler, 2014), jika penelitian didesain untuk memperluas dan bukan untuk memperdalam penelitian, maka penelitian tersebut termasuk statistical study. Penelitian statistical study berusaha menangkap karakteristik dari populasi dengan membuat inferensi dari karakteristik sampel serta hipotesis diuji secara kuantitatif. Berdasarkan setting penelitiannya, penelitian ini termasuk dalam penelitian studi lapangan (field study) karena penelitian ini dilakukan pada kondisi lingkungan yang sebenarnya yaitu pada pemerintah desa di Kecamatan Karangawen Kabupaten Demak.

\section{Populasi Penelitian}

Populasi penelitian ini adalah seluruh perangkat desa yang terlibat dalam pengelolaan dana desa. Dalam penelitian ini unit analisis yang diteliti adalah perangkat desa yang mempunyai hak dan kewajiban dalam proses pengelolaan keuangan desa yang terdiri dari kepala desa, sekretaris desa, bendahara, pelaksana kegiatan pembangunan, pelaksana kegiatan pemerintahan, ketua tim pengelola kegiatan dan tim penggerak kesejahterahteraan keluarga pada 12 desa.

\section{Teknik Pengambilan Sampel}

Teknik pengambilan sampel yang digunakan dalam penelitian ini adalah metode sensus, dalam penelitian ini berjumlah 84 responden.

\section{Teknik Pengumpulan Data}

Metode pengumpulan data dalam penelitian ini dilakukan dengan kuesioner pada perangkat desa yang terlibat dalam pengelolaan dana desa. 


\section{Variabel dan Definisi Operasional Varia- bel}

Kinerja Pengelolaan Keuangan Desa

Kinerja pengelolaan keuangan desa adalah hasil kerja atau prestasi aparatur desa dalam melaksanakan seluruh kegiatan meliputi perencanaan, pelaksanaan, pelaporan, dan pertanggung jawaban keuangan desa (Munti dan Fahlevi, 2017). Indikator kinerja pengelolaan keuangan desa (Mardiasmo, 2009) terdiri dari 1) Efisiensi, 2) Efektifitas, 3) Ekonomis, 4) Pelaporan yang memadai.

\section{Transparansi}

Kebebasan dan keterbukaan memperoleh informasi untuk dapat diakses dengan mudah oleh masyarakat (Astuti dan Yulianto, 2016). Indikator transaparansi (Astuti dan Yulianto, 2016) terdiri dari 1) Mekanisme yang menjamin sistem keterbukaan dan standarisasi dari semua proses pelayanan publik; 2) Mekanisme yang memfasilitasi pertanyaan-pertanyaan publik tentang berbagai kebijakan dan pelayanan publik, maupun proses-proses didalam sektor publik; 3) Mekanisme yang memfasilitasi pelaporan maupun penyebaran informasi maupun penyimpangan tindakan aparat publik di dalam kegiatan melayani.

\section{Akuntabilitas}

Kewajiban bagi pemerintah desa untuk memberikan pertanggungjawaban, menyajikan dan mengungkapkan segala aktivitasnya dan kegiatan yang menjadi tanggung jawabnya (Astuti dan Yulianto, 2016). Indikator akuntabilitas (Astuti dan Yulianto, 2016) terdiri dari 1) komitmen pimpinan dan staf, 2) konsisten dengan UU yang berlaku, 3) pencapaian tujuan dan sasaran yang ditetapkan, 4) berorientasi pada pencapaian visi dan misi, 5) jujur, obyektif, transparan dan inovatif.

\section{Partisipasi Masyarakat}

Keikutsertaan masyarakat dalam segala hal yang berhubungan untuk pengambilan keputusan yang demokratis serta dalam program dan kegiatan desa (Astuti dan Yulianto, 2016). Indikator partisipasi masyarakat (Astuti dan Yulianto, 2016) terdiri dari 1) adanya akses bagi partisipasi aktif publik dalam proses perumusan program dan pengambilan keputusan anggaran, 2) adanya peraturan yang memberikan tempat ruang kontrol oleh lembaga independen dan masyarakat baik secara perorangan maupun kelembagaan sebagai media check andbalances, 3) adanya sikap proaktif pemerintah daerah untuk mendorong partisipasi warga pada proses penganggaran.

\section{Kapasitas Aparatur Desa}

Kemampuan aparatur desa dalam menjalankan fungsinya sebagai pengelolaan keuangan berupa kompetensi akuntansi yang baik sehingga mampu memahami logika akuntansi yang menjadi dasar dalam pengelolaan keuangan yang profesional (Rafar, Fahlevi, dan Basri, 2015). Indikator kapasitas aparatur desa (Rafar, Fahlevi, dan Basri, 2015) terdiri dari: 1) Pemahaman, 2) Keterampilan, 3) Kemampuan.

\section{Sistem Pengendalian Internal}

Pengawasan merupakan tahap integral untuk menjamin dari keseluruhan tahap pada penyusunan pelaksanaan, dan pelaporan APBD, sesuai rencana dan ketentuan peraturan (Tarjono dan Nugraha, 2015). Indikator pengendalin internal (Dra$\mathrm{ma}, 2014)$ terdiri dari 1) lingkungan pengendalian, 2) penilaian resiko, 3) kegiatan pengendalian, 4) informasi dan komunikasi, 5) pemantauan.

\section{Teknik Analisis}

Teknik Analisis yang digunakan adalah Structural Equation Modeling (SEM) dengan menggunakan program WrapPLS 5.0. Dengan metode PLS maka akan dilakukan uji model yang meliputi Outer Model dan Inner Model.

Adapun Model penelitian dapat dilihat pada Gambar 1. 


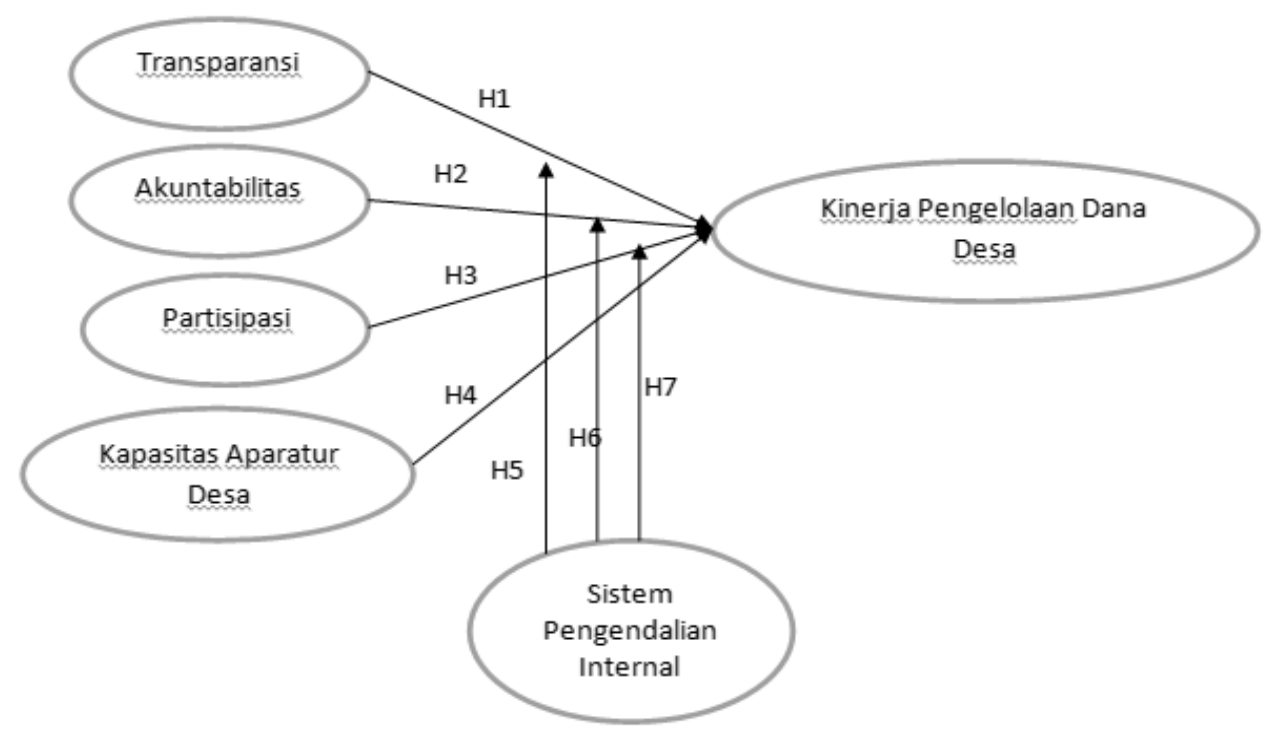

Gambar 1

Model Penelitian

\section{ANALISIS DAN PEMBAHASAN}

Penelitian ini mengambil objek pada perangkat desa yang terlibat dalam pengelolaan dana desa. Dari 84 kuesioner yang dapat digunakan, didapatkan informasi mengenai karakteristik responden yang berpartisipasi dalam penelitian ini dengan deskripsi responden seperti pada Tabel 1.

Tabel 1

\section{Deskripsi Responden}

\begin{tabular}{|c|c|c|}
\hline Karakteristik & Jumlah & Prosentase \\
\hline \multicolumn{3}{|l|}{ I. USIA } \\
\hline 23-28 tahun & 5 & $5.95 \%$ \\
\hline 29-34 tahun & 13 & $15.48 \%$ \\
\hline 35-40 tahun & 27 & 32.145 \\
\hline 41-46 tahun & 33 & $40.48 \%$ \\
\hline 47-52 tahun & 6 & $5.95 \%$ \\
\hline Total & 84 & $100 \%$ \\
\hline \multicolumn{3}{|l|}{ II. Jenis Kelamin } \\
\hline Laki-Laki & 61 & $72.62 \%$ \\
\hline Perempuan & 23 & $27.38 \%$ \\
\hline Total & 84 & $100 \%$ \\
\hline \multicolumn{3}{|l|}{ III. Pendidikan } \\
\hline SLTP & 1 & $1.2 \%$ \\
\hline SLTA & 51 & $60.71 \%$ \\
\hline D3 & 3 & $3.57 \%$ \\
\hline S1 & 27 & $32.14 \%$ \\
\hline$S 2$ & 2 & $2.38 \%$ \\
\hline Total & 84 & $100 \%$ \\
\hline
\end{tabular}

IV. Jabatan

\begin{tabular}{lcc} 
Kepala Desa & 12 & $\mathbf{1 4 . 2 9 \%}$ \\
$\begin{array}{l}\text { Sekretaris Desa } \\
\text { Bendahara }\end{array}$ & 12 & $\mathbf{1 4 . 2 9 \%}$ \\
$\begin{array}{l}\text { Pelaksana Kegiatan } \\
\text { Pembangunan }\end{array}$ & 12 & $\mathbf{1 4 . 2 9 \%}$ \\
$\begin{array}{l}\text { Pelaksana Kegiatan } \\
\text { Pemerintahan }\end{array}$ & 12 & $\mathbf{1 4 . 2 9 \%}$ \\
$\begin{array}{l}\text { Ketua TPK } \\
\text { TP PKK }\end{array}$ & 12 & $\mathbf{1 4 . 2 9 \%}$ \\
\hline & 12 & $\mathbf{1 4 . 2 9 \%}$ \\
$\quad$ Total & $\mathbf{8 4}$ & $\mathbf{1 4 . 2 9 \%}$ \\
\hline
\end{tabular}

Sumber : Data Primer yang diolah

Dari Table 1 dapat dijelaskan bahwa sebagian besar responden 41-46 tahun, jenis kelamin laki-laki dengan tingkat pendidikan sebagian besar SLTA. Hal ini menunjukkan bahwa sebagian besar pemerintah desa memiliki usia yang relatif matang dalam pengambilan keputusan, namun dalam pendidikannya relative masih tergolong menengah karena sebagian besar hanya berpendidikan SLTA. Semua pihak perangkat desa telah terlibat dalam pengambilan keputusan terkait dengan pengelolaan dana desa.

\section{Analisis Data Penelitian}

Penelitian ini menggambarkan bagaimana persepsi pengelolaan dana desa dengan menggunakan prinsip good governance dengan system pengendalian internal. 
Pada masing-masing item pertanyaan yang diberikan diperleh jawaban pada Tabel 2. Dari Tabel 2 dapat dijelaskan bahwa pada transparansi seluruh indikator 1 sampai dengan 3 memiliki nilai modus 4 . Rata-rata tertinggi dari indikator transparansi adalah

Tabel 2

Statistik Deskriptif Variabel Penelitian

\begin{tabular}{lll}
\hline \multicolumn{1}{c}{ Variabel } & & \\
\hline Transparansi & Mean & Mode \\
\hline T1 & 3.857 & 4 \\
T2 & 3.833 & 4 \\
T3 & 3.928 & 4 \\
\hline Akuntabilitas & Mean & Mode \\
\hline AK1 & 3.893 & 4 \\
AK2 & 3.786 & 4 \\
Ak3 & 3.81 & 4 \\
AK4 & 3.92 & 4 \\
AK5 & 3.89 & 4 \\
\hline Partisipasi & Mean & Mode \\
Masyarakat & & \\
\hline PM1 & 3.953 & 4 \\
PM 2 & 4 & 4 \\
PM3 & 3.83 & 4 \\
\hline Kapasitas Aparatur & Mean & Mode \\
Desa & & \\
\hline KAD1 & 3.797 & 4 \\
KAD2 & 3.821 & 4 \\
KAD3 & 3.917 & 4 \\
\hline Sistem & Mean & Mode \\
Pengendalian & & \\
internal & & \\
\hline SPI1 & 4.023 & 4 \\
SPI2 & 3.769 & 4 \\
SPI3 & 3.845 & 4 \\
SPI4 & 3.988 & 4 \\
SPI5 & 3.821 & 4 \\
\hline Kinerja & Mean & Mode \\
\hline K1 & 3.881 & 4 \\
K2 & 3.786 & 4 \\
K3 & 3.892 & 4 \\
K4 & 3.940 & 4 \\
\hline Sur & & \\
\hline
\end{tabular}

Sumber: Data Primer yang diolah

pada T3 yaitu pemerintah desa memfasilitasi penyebarluasan informasi penge- lolaan keuangan desa, dan yang terendah adalah T1 Pemerintah desa menyediakan informasi public secara terbuka agar masyarakat dapat mengetahui penggunaan dari APB Desa. Hal ini memberi gambaran bahwa rata-rata transparansi pengelolaan keuangan desa telah dilakukan secara transparan oleh pemerintah desa. Pada akuntabilitas seluruh indikator 1 sampai dengan 5 memiliki nilai modus 4 Nilai ratarata tertinggi dari indikator akuntabilitas adalah pada AK 4 yaitu pengelolaan keuangan desa berorientasi pada pencapaian visi dan misi desa dan yang terrendah adalah AK 2 Pengelolaan keuangan desa, dilakukan konsisten sesuai dengan UU yang berlaku. Hal ini memberi gambaran bahwa secara keseluruhan akuntabiitas telah dilakukan oleh aparat desa dalam pelaksanaan dana desa.

Pada variabel partisipasi masyarakat seluruh indikator PM1 sampai PM 3 mempunyai mode 4 , nilai rata-rata tertinggi dari indikator adalah pada PM2 yaitu Pemerintah Desa memberikan ruang control bagi masyarakat untuk terlibat aktif guna melakukan check and balance dalam pengelolaan keuangan desa dan yang terrendah adalah PM3 yaitu Pemerintah desa proaktif melibatkan seluruh elemen masyarakat dalam kegiatan pengelolaan keuangan desa. Hal ini memberi gambaran bahwa seecara keseluruhan partisipasi masyarakat telah dilakukan oleh aparat desa dalam pelaksanaan alokasi dana desa, hanya perlu peningkatan dari pemerintah desa untuk lebih poraktif melibatkan seluruh masyarakat.

Nilai mode pada kapasitas aparatur desa dari indicator 1 sampai 3 adalah 4 . Nilai rata-rata tertinggi dari indikator Kapasitas Aparatur Desa adalah pada KAD3 yaitu Aparat perangkat desa memiliki kemampuan dalam mengelola dana desa dan yang terendah adalah KAD1 yaitu Aparat perangkat desa sudah dapat memahami isi dari peraturan-peraturan terkait pengelolaan dana desa. 
Hal ini memberi gambaran bahwa secara umum aparat desa sudah memiliki kapasitas atau kemampuan dalam mengelola dana desa. Nilai mode indikator system pengendalian internal dari indikator 1 sampai 5 adalah 4 , rata-rata tertinggi adalah pada SP1 yaitu Pemerintah desa menetapkan struktur organisasi yang tepat dalam rangka pengelolaan keuangan desa dan yang terrendah adalah SPI 2 yaitu Pemerintah desa mampu mengidentifikasi resiko-resiko dalam pengelolaan keuangan desa. Hal ini memberi gambaran bahwa secara umum system pengendalian internal telah dilakukan oleh aparat desa namun perlu peningkatan dalam mengidentifikasi resiko dalam pengelolaan keuangan desa.

Mode pada indikator kinerja 1 sampai kinerja 4 adalah 4 . Nilai rata-rata tertinggi dari indikator kinerja pengeloaan keuangan desa adalah pada K4 yaitu Laporan keuangan desa diperiksa oleh Inspektorat dan Pemdes melakukan analisis laporan keuangan untuk dapat mengetahui keberhasilan dari pelaksanaan anggaran dan yang terrendah adalah K2 yaitu hasil Pengelolaan Keuangan Desa sesuai dengan tujuan dan sasaran atau target yang ditetapkan. Hal ini memberi gambaran bahwa secara umum Kinerja pengelolaan keuangan desa telah berjalan optimal hanya perlu penambahan pemantauan dalam kesesuaian sasaran yang ditetapkan.

\section{Evaluasi Model Pengukuran (Outer Model)}

Evaluasi model pengukuran atau outer model dilakukan untuk menilai validitas dan reliabilitas model. Hasil uji Validitas dan Reliabilitas diringkas pada Tabel 3 serta Gambar 1. Penilaian validitas meliputi validitas convergent dan validitas discriminant. Kriteria penilaian uji validitas convergent menurut Hair (2017) adalah bila outer loading lebih dari 0,70 maka keandalan baik, nilai reliabilitas $0,40-<0,60$ menganalisa dampak penghapusan indikator pada konsistensi reliabilitas, yaitu bila penghapusan meningkatkan ukuran di atas ambang batas, maka indicator reflektif dihapus tetapi mempertimbangkan content validity, namun bila penghapusan tidak eningkatkan ukuran di atas ambang batas, maka indikator reflektif dipertahankan, sedangkan bila nilai outer loading kurang dari 0,4 maka indikator reflektif dihapus tetapi pertimbangkan dampaknya pada content validity.

Tabel 3

Hasil Uji Validitas dan Reliabilitas

\begin{tabular}{|c|c|c|c|c|c|}
\hline $\begin{array}{l}\text { Vari } \\
\text { abel }\end{array}$ & $\begin{array}{l}\text { Indi } \\
\text { kator }\end{array}$ & $\begin{array}{l}\text { Outer } \\
\text { Loa } \\
\text { ding }\end{array}$ & CR & AVE & DV \\
\hline \multirow[t]{3}{*}{$\mathrm{T}$} & $\mathrm{T} 1$ & 0811 & 0.88 & 0.722 & 0.85 \\
\hline & $\mathrm{T} 2$ & 0.882 & & & \\
\hline & T3 & 0.855 & & & \\
\hline \multirow[t]{5}{*}{ A } & AK1 & 0.722 & 0.86 & 0.571 & 0.76 \\
\hline & AK2 & 0.731 & & & \\
\hline & AK3 & 0.751 & & & \\
\hline & $\mathrm{AK} 4$ & 0.808 & & & \\
\hline & AK5 & 0.762 & & & \\
\hline \multirow[t]{3}{*}{ PM } & PM1 & 0.834 & 0.83 & 0.623 & 0.79 \\
\hline & PM2 & 0.755 & & & \\
\hline & PM3 & 0.776 & & & \\
\hline \multirow[t]{3}{*}{ KAD } & KAD1 & 0.780 & 0.84 & 0.65 & 0.81 \\
\hline & KAD2 & 0.808 & & & \\
\hline & KAD3 & 0.829 & & & \\
\hline \multirow[t]{5}{*}{ SPI } & SPI1 & 0.839 & 0.88 & 0.601 & 0.78 \\
\hline & SPI2 & 0.754 & & & \\
\hline & SPI3 & 0.802 & & & \\
\hline & SPI4 & 0.730 & & & \\
\hline & SPI5 & 0.747 & & & \\
\hline \multirow[t]{4}{*}{ K } & $\mathrm{K} 1$ & 0.911 & 0.81 & 0.736 & 0.86 \\
\hline & $\mathrm{K} 2$ & 0.850 & & & \\
\hline & K3 & 0.861 & & & \\
\hline & K4 & 0.805 & & & \\
\hline
\end{tabular}

Sumber: Data primer yang diolah

Keterangan

AVE $=$ Average Variance Extract

$\mathrm{CR}=$ Composite Reliability

$\mathrm{DV}=$ Discriminant Validity

Hasil uji outer loadings menunjukkan nilai lebih dari rule of tumbs 0,70. Semua indikator pada variabel transparansi, akun tansi partisipasi, kapasitas aparatur, system pengendalian dan kinerja bernilai lebih dari 0,7 . Dengan demikan dapat dikatakan 
bahwa seluruh variabel memiliki validitas konvergen yang baik.

Penilaian validitas convergent juga dilakukan melalui nilai Average Variance Extract (AVE) dengan ketentuan $>0,50$ untuk confirmatory dan exploratory research (Hair, 2017). Hasil pengujian validitas konvergen menggunakan AVE menunjukkan bahwa nilai AVE masing-masing konstruk telah memenuhi syarat diatas 0,5 .

Pengujian validitas diskriminan dilakukan dengan melihat nilai discriminant validity (DV). Perhitungan (discriminant validity) pada Tabel 3 dapat disimpulkan bahwa semua variabel memiliki korelasi tertinggi pada dirinya sendiri dibandingkan dengan korelasi pada variabel lain. Dengan demi- kian, syarat validitas diskriminan pada penelitian ini terpenuhi.

Reliabilitas model pengukuran dinilai dengan cara melihat nilai composite reliability $(C R)$, dengan ketentuan jika $C R<0,6$ menunjukkan kurangnya keandalan konsistensi internal, jika CR antara 0,60 - 0,70 masih dapat diterima untuk exploratory research, jika CR bernilai antara 0,70 dan 0,90 dapat dianggap memuaskan dan jika CR bernilai lebih dari 0,90 tidak diinginkan karena menunjukkan semua variabel indikator mengukur fenomena yang sama (Hair, 2017). Dari hasil penelitian pada table 3 menunjukkan bahwa nilai $\mathrm{CR}$ berkisar antara 0,7 - 0,9 sehingga dianggap memiliki nilai reliabilitas komposit memuaskan.

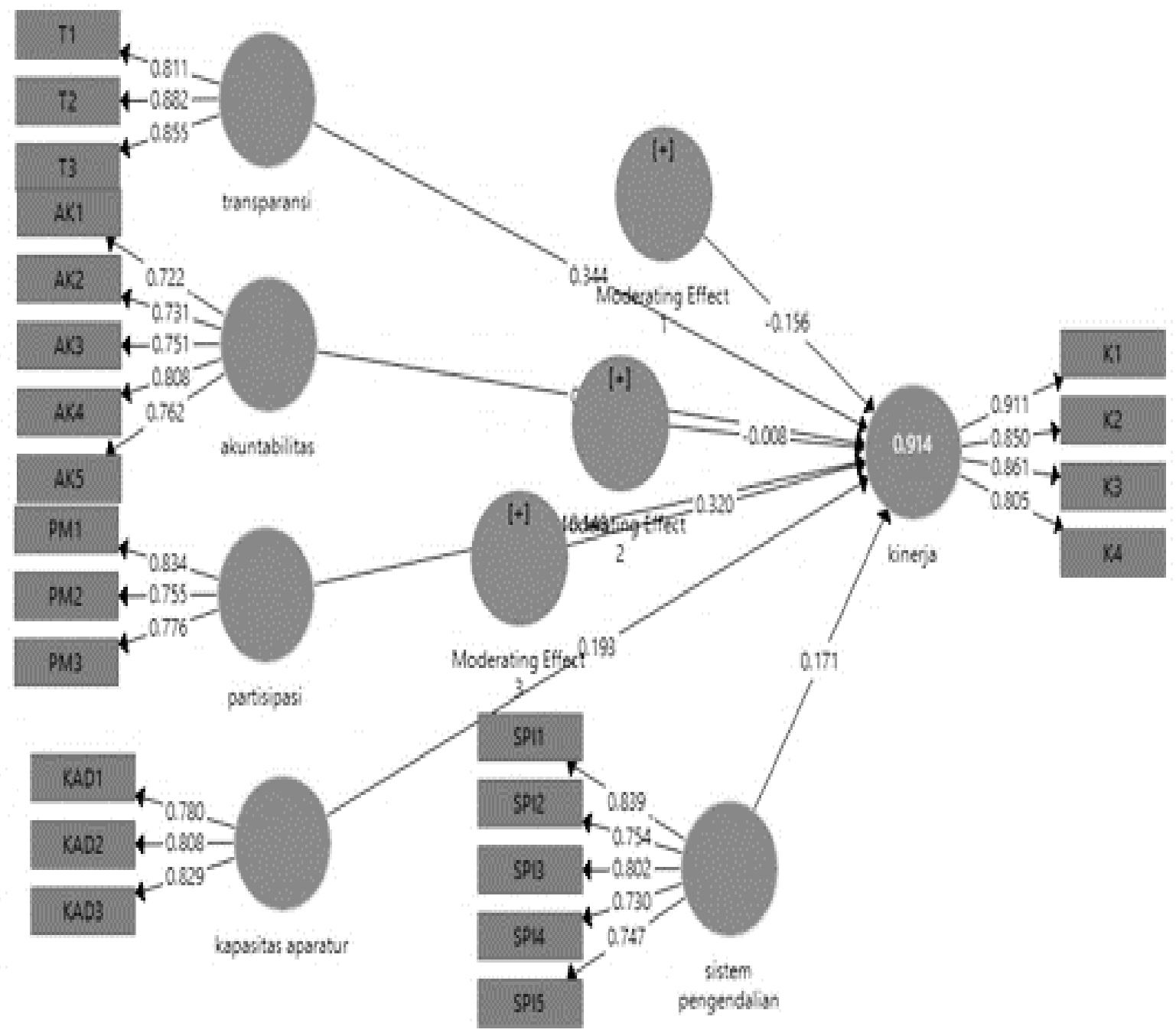

Gambar 2

Hasil Uji Outer Model 


\section{Evaluasi Model Struktural (Inner Model)}

Penilaian model struktural menggunakan PLS dengan melihat nilai $R$-Square untuk setiap variabel laten endogen sebagai kekuatan prediksi dari model structural. Nilai R-Square merupakan uji goodness fit model. Perubahan nilai $R$-Square digunakan untuk menjelaskan pengaruh variabel laten eksogen tertentu terhadap variabel endogen, apakah mempunyai pengaruh substantif.

Hasil dari PLS R-Square mempresentasikan jumlah variance dari konstruk yang dijelaskan oleh model. Kriteria penilaian evaluasi model struktural adalah jika $R$ square bernilai 0,67 atau lebih menunjukkan bahwa model kuat; $R$ square bernilai 0,33 menunjukkan model moderat dan 0,19 menunjukkan model lemah. Nilai $R$-square sebesar 0,914 berarti model kuat, dimana variabilitas konstruk kinerja yang dapat dijelaskan oleh konstruk partisipasi, akuntabilitas, transparansi, sistem pengendalian, kapasitas aparatur dan interaksinya sebesar $91,4 \%$.

\section{Uji Hipotesis}

Pengujian Hipotesis menggunakan PLS dengan melihat nilai $\mathrm{p}$ value atau nilai $\mathrm{t}$ pada masing-masing hipotesis. Rule of tumbs dari terdukungnya suatu hipotesis penelitian adalah: (1) jika koefesien atau arah hubungan variabel (ditunjukkan oleh nilai original sampel) sejalan dengan yang dihipotesiskan, dan (2) jika nilai t statistik lebih dari 1,64 (two-tiled) atau 1,96 (one-tiled) dan probability value ( $p$-value) kurang dari 0,05 atau 5\% (Hair, 2017).

Hasil Uji Hipotesis dengan menggunakan PLS dapat dilihat pada Tabel 4 berikut.

Tabel 4

Hasil Uji Hipotesis

\begin{tabular}{|c|c|c|c|c|c|}
\hline & $\begin{array}{l}\text { Original } \\
\text { Sample } \\
\text { (O) }\end{array}$ & $\begin{array}{l}\text { Sample } \\
\text { Mean } \\
\text { (M) }\end{array}$ & $\begin{array}{l}\text { Standard } \\
\text { Deviation } \\
\text { (STDEV) }\end{array}$ & $\begin{array}{l}\text { TStatistics } \\
\text { (|O/STERR|) }\end{array}$ & P Value \\
\hline $\begin{array}{l}\text { Moderating } \\
\text { effect l }>> \\
\text { kineria }\end{array}$ & -0.156 & -0.105 & 0.224 & 0.639 & 0.523 \\
\hline $\begin{array}{l}\text { Moderating } \\
\text { effect } 2 \text {-> } \\
\text { kinerja }\end{array}$ & -0.008 & 0.012 & 0.243 & 0.0035 & 0.972 \\
\hline $\begin{array}{l}\text { Moderating } \\
\text { effect } 3 \text {-> } \\
\text { kinerja }\end{array}$ & 0.320 & 0.226 & 0.226 & 1.412 & 0.159 \\
\hline $\begin{array}{l}\text { Akuntabilitas } \\
\rightarrow \text { kinerja }\end{array}$ & 0.225 & 0.211 & 0.088 & 2.557 & 0.011 \\
\hline $\begin{array}{l}\text { Kapasitas } \\
\text { aparatur -> } \\
\text { kinerja }\end{array}$ & 0.193 & 0.190 & 0.068 & 2.850 & 0.005 \\
\hline $\begin{array}{l}\text { Partisipasi -> } \\
\text { kinerja }\end{array}$ & 0.148 & 0.152 & 0.057 & 2.604 & 0.009 \\
\hline $\begin{array}{l}\text { Transparansi } \\
\rightarrow \text { kinerja }\end{array}$ & 0.344 & 0.359 & 0.084 & 4.102 & 0.00 \\
\hline
\end{tabular}

Sumber: Data primer yang diolah. 
Pengaruh Transparansi terhadap Kinerja Pengelolaan Dana Desa di Kecamatan Karangawen Kabupaten Demak

Uji hubungan antar konstruk menunjukkan bahwa konstruk transparansi berpengaruh positif signifikan terhadap kinerja dengan koefisien parameter sebesar 0,344 dan signifikan pada $5 \%$ (t hitung $4,102>1,96$ dan signifikansi kurang dari 0,05 yaitu sebesar 0,00 ).

Pengaruh Akuntabilitas terhadap Kinerja Pengelolaan Dana Desa di Kecamatan Karangawen Kabupaten Demak

Uji hubungan antar konstruk menunjukkan bahwa konstruk akuntabilitas berpengaruh positif signifikan terhadap kinerja dengan koefisien parameter sebesar 0,225 dan signifikan pada 5\% ( $\mathrm{t}$ hitung 2,557 $>$ 1,96 dan signifikansi kurang dari 0,05 yaitu sebesar 0,011).

Pengaruh Partisipasif terhadap Kinerja Pengelolaan Dana Desa di Kecamatan Karangawen Kabupaten Demak

Uji hubungan antar konstruk menunjukkan bahwa konstruk partisipasif berpengaruh positif signifikan terhadap kinerja dengan koefisien parameter sebesar 0,148 dan signifikan pada 5\% (t hitung 2,604 > 1,96 dan signifikansi kurang dari 0,05 yaitu sebesar 0,009 ).

Pengaruh Kapasitas Aparatur Pemerintah Desa terhadap Kinerja Pengelolaan Dana Desa di Kecamatan Karangawen Kabupaten Demak

Uji hubungan antar konstruk menunjukkan bahwa konstruk kapasitas aparatur berpengaruh positif signifikan terhadap kinerja dengan koefisien parameter sebesar 0,193 dan signifikan pada 5\% (t hitung 2,850 > 1,96 dan signifikansi kurang dari 0,05 yaitu sebesar 0,005).

Sistem Pengendalian Internal Memoderasi Hubungan Transparansi dengan Kinerja Pengelolaan Dana Desa di Kecamatan Karangawen Kabupaten Demak
Konstruk interaksi antara transparansi dan sistem pengendalian tidak signifikan mempengaruhi kinerja hal ini ditunjukkan dengan nilai $t$ hitung sebesar 0,639 kurang dari $t$ tabel 1,96. Sehingga sistem pengendalian internal gagal menjadi variabel moderasi hubungan transparansi terhadap kinerja pengelolaan dana desa.

Sistem Pengendalian Internal Memoderasi Hubungan Akuntabilitas dengan Kinerja Pengelolaan Dana Desa di Kecamatan Karangawen Kabupaten Demak

Konstruk interaksi antara akuntabilitas dan sistem pengendalian tidak signifikan mempengaruhi kinerja hal ini ditunjukkan dengan nilai $\mathrm{t}$ hitung sebesar 0,0035 kurang dari $t$ tabel 1,96 . Sehingga sistem pengendalian internal gagal menjadi variabel moderasi hubungan akuntabilitas terhadap kinerja pengelolaan dana desa.

Sistem Pengendalian Internal Memoderasi Hubungan Partisipasi dengan Kinerja Pengelolaan Dana Desa di Kecamatan Karangawen Kabupaten Demak

Konstruk interaksi antara partisipasi dan sistem pengendalian tidak signifikan mempengaruhi kinerja hal ini ditunjukkan dengan nilai $t$ hitung sebesar 1,412 kurang dari $t$ tabel 1,96. Sehingga sistem pengendalian internal gagal menjadi variabel moderasi hubungan partisipasi terhadap kinerja pengelolaan dana desa. Secara umum hasil pengujian hipotesis dapat diringkas pada Table 5.

\section{Pembahasan}

Transparansi Berpengaruh Positif Signifikan terhadap Kinerja Pengelolaan Dana Desa di Kecamatan Karangawen Kabupaten Demak

Sebagai bentuk dari implementasi good governance terkait pengelolaan dana desa, Kabupaten Demak memiliki terobosan baru dengan meluncurkan aplikasi Desa Waskita yang digagas oleh Kepala Inspektorat Kabupaten Demak. Melalui portal www. apbdes. inspektoratdmk.co.id tersebut semua pe- 
Tabel 5

Ringkasan Hasil Uji Hipotesis

\begin{tabular}{|c|c|c|c|}
\hline \multicolumn{2}{|c|}{ Hipotesis } & Hasil Pengujian & Simpulan \\
\hline \multicolumn{4}{|c|}{$\begin{array}{l}\text { Pengaruh Langsung Good Corporate Governance dan Kapasitas Aparatur Desa terhadap } \\
\text { Kinerja Pengelolaan Dana Desa }\end{array}$} \\
\hline $\mathrm{H}_{1}$ & $\begin{array}{l}\text { Tranaparansi bepengaruh terhadap } \\
\text { Kinerja pengelolaan Dana Desa }\end{array}$ & $\begin{array}{l}\text { Positif, } \\
\text { Signifikan }\end{array}$ & Hipotesis didukung \\
\hline $\mathrm{H}_{2}$ & $\begin{array}{l}\text { Akuntabilitas Berpengaruh terhadap } \\
\text { Kinerja Pengelolaan Dana Desa }\end{array}$ & $\begin{array}{l}\text { Positif, } \\
\text { Signifikan }\end{array}$ & Hipotesis didukung \\
\hline $\mathrm{H}_{3}$ & $\begin{array}{l}\text { Partisipasi Berpengaruh terhadap } \\
\text { Kinerja Pengelolaan Dana Desa }\end{array}$ & $\begin{array}{l}\text { Positif, } \\
\text { Signifikan }\end{array}$ & Hipotesis didukung \\
\hline $\mathrm{H}_{4}$ & $\begin{array}{l}\text { Kapasitas Aparatur Desa Berpe- } \\
\text { ngaruh terhadap Kinerja Pengelolaan } \\
\text { Dana Desa }\end{array}$ & $\begin{array}{l}\text { Positif, } \\
\text { Signifikan }\end{array}$ & Hipotesis didukung \\
\hline \multicolumn{2}{|c|}{ Hipotesis } & Hasil & Simpulan \\
\hline \multicolumn{4}{|c|}{$\begin{array}{l}\text { Pengaruh Moderasi Sistem pengendalian Internal pada Peng } \\
\text { Governance terhadap Kinerja Pengelola Dana Desa } \\
\mathrm{H}_{5} \quad \text { Sistem Pengendalian Internal Mem- Positif }\end{array}$} \\
\hline & $\begin{array}{l}\text { Sistem Pengendalian Internal Mem- } \\
\text { perkuat Pengaruh Transparansi ter- } \\
\text { hadap Kinerja Pengelolaan Dana Desa }\end{array}$ & $\begin{array}{l}\text { Positif, } \\
\text { Tidak Signifikan }\end{array}$ & $\begin{array}{l}\text { Hipotesis tidak } \\
\text { didukung }\end{array}$ \\
\hline $\mathrm{H}_{6}$ & $\begin{array}{l}\text { Sistem Pengendalian Internal Mem- } \\
\text { perkuat Pengaruh Akuntabilitas ter- } \\
\text { hadap Kinerja Pengelolaan Dana Desa }\end{array}$ & $\begin{array}{l}\text { Positif, } \\
\text { Tidak Signifikan }\end{array}$ & $\begin{array}{l}\text { Hipotesis tidak } \\
\text { didukung }\end{array}$ \\
\hline $\mathrm{H}_{7}$ & $\begin{array}{l}\text { Sistem Pengendalian Internal Mem- } \\
\text { perkuat Pengaruh Partisipasi ter- } \\
\text { hadap Kinerja Pengelolaan Dana } \\
\text { Desa }\end{array}$ & $\begin{array}{l}\text { Positif, } \\
\text { Tidak Signifikan }\end{array}$ & $\begin{array}{l}\text { Hipotesis tidak } \\
\text { didukung }\end{array}$ \\
\hline
\end{tabular}

laporan pengelolaan dana desa untuk desadesa di Kabupaten Demak dapat dipantau langsung oleh publik (Kurniawan, 2018). Semua desa wajib menyampaikan laporan rutin melalui aplikasi tersebut, sebagai bentuk transparansi desa dalam mengelola dana desa. Desa yang memiliki pelaporan keuangan yang bagus akan mendapat opini Desa Waskita Tanpa Cidra atau desa mandiri tanpa penyimpangan. Salah satu tujuan dari aplikasi ini adalah agar terbentuk desa mandiri yaitu pemerintahan desa yang mengedepankan transparansi, akuntabel, dan partisipasif (Kurniawan, 2018).

Transparansi merupakan salah satu prinsip dari good governance. Transparansi dibangun di atas dasar arus informasi yang bebas, seluruh proses pemerintahan, lembaga-lembaga dan informasi perlu diakses oleh pihak-pihak yang berkepentingan, dan informasi yang tersedia harus memadai agar dapat dimengerti dan dipantau (Coryanata, 2007). Kemudian Danin (2005) mendefinisikan transparansi sebagai keterbukaan informasi, baik dalam proses pengambilan keputusan maupun dalam mengungkapkan informasi material dan relevan. Hal ini sejalan dengan penelitian Risya Umami dan Idang Nurodin (2017) yang menyatakan bahwa transparansi dapat memberikan jaminan akses informasi yang terbuka kepada semua orang dan masyarakat untuk memperoleh informasi keuangan maupun kebijakan yang diambil oleh pemerintah. Selanjutnya, dijelaskan bahwa prinsip transparansi dalam pengelolaan keuangan dapat dilaksanakan melalui sosialisasi kepada masyarakat di setiap pencairan dana dari pendapatan transfer, pemasangan baliho tentang Laporan Pertanggungjawaban dari Realisasi Anggaran Pendapatan dan Belanja Desa. Transparansi 
yakni adanya kebijakan terbuka bagi pengawasan.

Transparansi merupakan prinsip di mana menjamin akses atau kebebasan bagi setiap orang untuk mendapatkan informasi tentang organisasi tersebut. Transparansi berpengaruh terhadap kinerja organisasi, dikarenakan sebuah transparansi merupakan suatu alat yang digunakan oleh agent untuk menunjukkan bahwa harapan atau tujuan yang diinginkan oleh principal telah dipublikasikan. Hal ini akan mempengaruhi kinerja dari organisasi tersebut.

\section{Akuntabilitas Berpengaruh Positif Signi- fikan terhadap Kinerja Pengelolaan Dana Desa di Kecamatan Karangawen Kabu- paten Demak}

Dana Desa harus dimanfaatkan dan digunakan untuk kepentingan Desa dan pelaksanaannya diawasi bersama serta dilengkapi dengan laporan-laporan secara tertulis agar dapat dipertanggungjawabkan. Jika masyarakat menemukan kejanggalan dapat langsung ditanyakan kepada Kelapa Desa atau BPD. Laporan-laporan tersebut, sebagai contoh laporan keuangan merupakan bentuk akuntabilitas dari pengelolaan dana desa. Laporan keuangan digunakan untuk mempertanggungjawabkan sumbersumber daya ekonomi yang telah dimanfaatkan. Mardiasmo (2012) mendefinisikan akuntabilitas merupakan sebuah kewajiban untuk melaporkan dan mempertanggung jawabkan atas keberhasilan ataupun kegagalan pelaksanaan misi organisasi dalam mencapai hasil yang telah ditetapkan sebelumnya, melalui media pertanggungjawaban yang dikerjakan secara berkala. Sedangkan, Danin (2005) mendefinisikan akuntabilitas sebagai kejelasan fungsi, struktur, sistem, dan pertanggungjawaban organ perusahaan sehingga pengelolaan perusahaan terlaksana secara efektif.

Ahdiyana (2008) menyimpulkan jika akuntabilitas berhubungan dengan kewajiban dari institusi atau aparat yang bekerja di dalamnya untuk membuat kebijakan atau melakukan tindakan yang sesuai dengan nilai yang berlaku maupun kebutuhan masyarakat. Akuntabilitas publik menuntut adanya pembatasan tugas yang jelas dan efisien dari para aparat. Risya Umami dan Idang Nurodin (2017) juga menyebutkan akuntabilitas merupakan pertanggungjawaban oleh lembaga yang diberi wewenang dalam mengelola sumber daya publik. Akuntabilitas berpengaruh terhadap kinerja organisasi dikarenakan, akuntabilitas adalah bentuk pertanggung jawaban dari agent kepada principal.

Mardiasmo (2012) mendefinisikan bahwa akuntabilitas publik merupakan kewajiban pihak pemegang amanah (agent) untuk memberikan pertanggungjawaban, dan mengungkapkan segala aktivitas dan kegiatan yang menjadi tanggung jawabnya kepada pihak pemberi amanah (principal) yang memiliki hak dan kewenangan untuk meminta pertanggungjawaban tersebut. Kesuksesan kinerja organisasi ditentukan dari keselarasan antara agent dan principal, akuntabilitas yang baik dalam organisasi akan mengurangi konflik yang terjadi. Sehingga akuntabilitas berpengaruh terhadap kesuksesan dari organisasi tersebut. Kesuksesan dari organisasi dapat dilihat dari kinerja yang baik, hal ini juga didukung oleh penelitian Risya Umami dan Idang Nurodin (2017) dan Gayatri, Made Yeni Latrini, Ni Luh Sari Widhiyani (2017)

\section{Partisipasif Berpengaruh Positif Signi- fikan terhadap Kinerja Pengelolaan Dana Desa di Kecamatan Karangawen Kabu- paten Demak}

Upaya yang dilakukan Pemdes Karangawen sebagai cerminan pelaksanaan good governance adalah melaksanakan rapat koordinasi pembahasan ADD (Alokasi Dana Desa) dan DD (Dana Desa) yang dilaksanakan di Aula Kantor Pertemuan Desa Tlogorejo Kecamatan Karangawen Kab. Demak. Rakor tersebut bertujuan agar seluruh elemen masyarakat sama-sama mengetahui pemanfaatan dan penggunaan anggaran. Hal ini menunjukkan adanya prinsip partisipasi. Partisipasi banyak me- 
nguntungkan bagi suatu organisasi. Melalui partisipasi masyarakat, organisasi dapat membuat suatu akuntabilitas organisasi tersebut semakin baik. Dalam sektor publik ataupun pemerintahan, partisipasi masyarakat berperan penting. Cornyata (2007) menyebutkan bahwa partisipasi masyarakat mempunyai peranan penting dalam otonomi daerah karena dalam partisipasi terdapat aspek pengawasan dan aspirasi.

Rita et al. (2011) menyebutkan bahwa partisipasi adalah prinsip bahwa setiap orang memiliki hak untuk terlibat dalam pengambilan keputusan di setiap kegiatan penyelenggaraan pemerintahan. Keterlibatan dalam pengambilan keputusan dapat dilakukan secara langsung atau secara tidak langsung. Partisipasi adalah prinsip bahwa setiap orang memiliki hak untuk terlibat dalam pengambilan keputusan di setiap kegiatan penyelenggaraan pemerintah. Partisipatif berarti bahwa setiap orang, siapa saja dapat turut serta dalam pengambilan keputusan. Partisipasi berpengaruh terhadap kinerja perangkat desa. Dalam pengelolaan dana desa partisipasi masyarakat dibutuhkan untuk membuat suatu keputusan.

Untuk menjalankan suatu akuntabilitas, partisipasi masyarakat dibutuhkan dalam penyusunan juga pengawasan terhadap organisasi. Hal ini dapat membuat tujuan antara agent dan principal berjalan lurus dan terhindar dari konflik. Cornyata (2007) menyebutkan bahwa partisipasi masyarakat mempunyai peranan penting dalam otonomi daerah karena dalam partisipasi terdapat aspek pengawasan dan aspirasi.

Kapasitas Aparatur Pemerintah Desa Berpengaruh Positif Signifikan terhadap Kinerja Pengelolaan Dana Desa di Kecamatan Karangawen Kabupaten Demak

Kapasitas dapat didefinisikan sebagai kemampuan manusia, lembaga dan masyarakat untuk melakukan keberhasilan, untuk mengidentifikasi dan mencapai tujuan mereka, dan untuk mengubah bila diperlu- kan untuk tujuan keberlanjutan, pengembangan dan kemajuan (Mouallem dan Analoui, 2014). Selanjutnya, kapasitas adalah pemahaman, sikap, kemampuan, keterampilan, nilai-nilai, hubungan, perilaku, sumber daya, motivasi dan kondisi-kondisi yang memberikan kemungkinan bagi setiap sistem, jaringan kerja, organisasi, dan individu untuk menerapkan fungsi-fungsi mereka dan mencapai tujuan pembangunan yang telah ditetapkan antar waktu. Dalam konteks pengelolaan keuangan, aparatur yang memiliki kapasitas berupa kompetensi akuntansi yang baik sehingga mampu memahami logika akuntansi yang menjadi dasar dalam pengelolaan keuangan yang professional (Rafar, Fahlevi, dan Basri, 2015).

Tjiptoherianto (2010) menjelaskan kinerja dan kualitas kapasitas sumber daya manusia dalam melaksanakan suatu fungsi, termasuk akuntansi, dapat dilihat dari level of responsibility dan kompetensi sumber daya tersebut. Islami (2016) menyatakan kapasitas merupakan suatau kemampuan yang dimiliki oleh individu suatu organisasi atau suatu sistem dalam melaksanakan fungsi-fungsinya secara efektif, efisien, dan berkelanjutan sesuai dengan aturan yang berlaku untuk mencapai tujuan bersama dalam pembangunan. Hal ini juga sejalan dengan penelitian yang dilakukan oleh Finta Munti dan Heru Fahlevi (2017).

\section{Sistem Pengendalian Internal Gagal Memoderasi Hubungan Transparansi de- ngan Kinerja Pengelolaan Dana Desa di Kecamatan Karangawen Kabupaten Demak}

Sistem pengendalian internal yang belum berjalan secara memadai tidak dapat memperkuat pengaruhnya ke kinerja (Hidayati dan Dianawati, 2017). Begitu juga sistem pengendalian internal yang efektif bukan merupakan jaminan akan kesuksesan suatu kinerja, sehingga interaksi antara pengendalian internal dan transparansi tidak dapat mempengaruhi kinerja pengelolaan dana desa, dengan kata lain 
sistem pengendalian internal gagal memoderasi hubungan transparansi dengan kinerja. Rerata skor pengendalian internal termasuk klasifikasi sedang hal ini berarti sistem pengendalian internal Pemerintah Desa di Kecamatan Karangawen belum memadai untuk mendukung kinerja pengelolaan keuangan desa.

\section{Sistem Pengendalian Internal Gagal} Memoderasi Hubungan Akuntabilitas dengan Kinerja Pengelolaan Dana Desa di Kecamatan Karangawen Kabupaten Demak

Nilai deskriptif jawaban responden menunjukkan bahwa sistem pengendalian internal telah dilakukan oleh aparat desa namun perlu peningkatan dalam mengidentifikasi resiko dalam pengelolaan keuangan desa. Hal ini menjadi salah satu penyebab sistem pengendalian internal gagal memoderasi hubungan akuntabilitas dengan kinerja pengelolaan dana desa. Pemerintah Kecamatan Karangawen belum optimal menilai dan menganalisis seluruh resiko kerugian yang terjadi dari pengelolaan dana desa. Sistem pengendalian internal yang belum optimal terutama pada pengidentifikasian resiko tidak mampu memperkuat hubungan suatu variabel terhadap kinerja organisasi (Hidayati dan Dianawati, 2017).

\section{Sistem Pengendalian Internal Gagal Memoderasi Hubungan Partisipasi dengan Kinerja Pengelolaan Dana Desa di Kecamatan Karangawen Kabupaten Demak}

Pengawasan merupakan tahap integral dengan keseluruhan tahap pada penyusunan dan pelaporan APBD. Pengawasan merupakan bagian dari sistem pengendalian internal yang menjadi bagian integral dari sebuah prinsip partisipasi. Sistem pengendalian internal gagal menjadi variabel moderasi karena sistem pengendalian internal merupakan bagian yang teriintegrasi dari prinsip partisipasi. Pengawasan di setiap tahapan pengelolaan keuangan daerah yang kurang efektif terutama pada pengidentifikasian resiko dalam keuangan desa tidak akan mampu memberi pengaruh yang kuat pada kinerja pengelolaan keuangan daerah. Hal ini sejalan dengan penelitian Hidayati dan Dianawati (2017) yang menyatakan bahwa unsur penilaian resiko tidak signifikan memperkuat pengaruh terhadap kinerja.

\section{SIMPULAN DAN SARAN \\ Simpulan}

Penelitian ini bermaksud untuk menganalisis persepsi aparatur pemerintah desa berdasarkan prinsip good governance (transparansi, akuntabilitas dan partisipasi), serta kapasitas aparatur pemerintah desa terhadap kinerja pengelolaan dana desa dengan sistem pengendalian internal sebagai variabel moderasi di Kecamatan Karangawen Kabupaten Demak. Sehingga hasil-hasil dari penelitian dapat disimpulkan Transparansi berpengaruh Positif Signifikan terhadap Kinerja Pengelolaan Dana Desa di Kecamatan Karangawen Kabupaten Demak.

Akuntabilitas berpengaruh Positif Signifikan terhadap Kinerja Pengelolaan Dana Desa di Kecamatan Karangawen Kabupaten Demak. Partisipasif Berpengaruh Positif Signifikan terhadap Kinerja Pengelolaan Dana Desa di Kecamatan Karangawen Kabupaten Demak, dan kapasitas Aparatur Pemerintah Desa Berpengaruh Positif Signifikan terhadap Kinerja Pengelolaan Dana Desa di Kecamatan Karangawen Kabupaten Demak.

Sistem Pengendalian Internal Gagal Memoderasi Hubungan Transparansi dengan Kinerja Pengelolaan Dana Desa di Kecamatan Karangawen Kabupaten Demak, Sistem Pengendalian Internal Gagal Memoderasi Hubungan Akuntabilitas dengan Kinerja Pengelolaan Dana Desa di Kecamatan Karangawen Kabupaten Demak, Sistem Pengendalian Internal Gagal Memoderasi Hubungan Partisipasi dengan Kinerja Pengelolaan Dana Desa di Kecamatan Karangawen Kabupaten Demak. 


\section{Saran}

Saran diambil berdasarkan nilai terrendah dari masing-masing indikator. Berikut adalah saran yang dapat diberikan antara lain adalah pemerintah desa menyediakan informasi publik secara terbuka agar masyarakat dapat mengetahui penggunaan dari APB Desa. Kondisi ideal ada satu website dari Pemerintah Desa Karangawen untuk mempublikasikan informasi kepada publik. Selain itu perangkat desa harus memahami tentang UU Keterbukaan Informasi Publik (KIP) yang memuat jenisjenis informasi yang secara berkala harus disediakan untuk publik, informasi yang wajib disediakan serta merta, informasi yang wajib disediakan setiap saat, informasi yang dikecualikan, dan informasi yang disediakan jika ada permintaan. Semua hal tersebut harus dimengerti oleh perangkat desa sehingga penyediaan informasi publik dapat dilaksanakan sesuai dengan peraturan. Pengelolaan keuangan desa, disarankan dilakukan dengan lebih konsisten sesuai dengan UU yang berlaku. Dalam hal ini keuangan desa harus dikelola dengan tertib dan disiplin anggaran, baik dalam penyusunan maupun pencairan anggaran yang sesuai termin dan tidak menumpuk di akhir tahun. Selain itu pelaporan pertanggungjawaban harus disampaikan tepat waktu.

Pemerintah desa disarankan untuk lebih proaktif melibatkan seluruh elemen masyarakat dalam kegiatan pengelolaan keuangan desa yaitu dalam rapat-rapat koordinasi pembahasan ADD (Alokasi Dana Desa) dan DD (Dana Desa).

Untuk meningkatkan kompetensi aparat perangkat desa dalam memahami isi dari peraturan-peraturan terkait pengelolaan dana desa, pemdes perlu untuk memberikan pelatihan-pelatihan, bimtek dan sosialisasi peraturan-peraturan yang terkait dengan pengelolaan dana desa.

Untuk meningkatkan sistem pengendalian internal, perangkat desa harus mampu mengidentifikasi resiko-resiko dalam pengelolaan keuangan desa. Pemdes harus mampu mengidentifikasi resiko tingkat entitas (program atau kegiatan tidak sesuai dengan aspirasi atau kebutuhan, kegagalan penyelenggaraan siklus pengelolaan dana desa yang sehat, kegagalan atau keterlambatan penyusunan laporan, pengelolaan aset desa yang tidak efisien), resiko fraud (penggunaan kas daerah secara tidak sah, mark up, pungutan liar, penggunaan untuk kepentingan pribadi, dan pungutan liar), serta resiko tingkat aktivitas (kesalahan penetapan tagihan dan penerimaan kas tidak disetor). Pengembangan Musrenbangdes dapat menjadi salah satu kegiatan untuk mencegah resiko-resiko tersebut

Hasil Pengelolaan Keuangan Desa harus lebih sesuai dengan tujuan dan sasaran atau target yang ditetapkan. Hal ini dapat dilakukan dengan memperkuat sistem pengendalian internal sebagai bentuk pengawasan agar tujuan dan sasaran dari pengelolaan desa dapat tercapai. Penguatan fungsi pengendalian dilakukan dengan melalui pembuatan sistem pengendalian intern yang efektif serta pemberdayaan auditor internal pemerintah.

\section{Keterbatasan Penelitian}

Pengukuran data-data kuantitatif hasil persepsi belum mampu menjadi tolok ukur atau ukuran konkret keberhasilan pengelolaan dana desa. Untuk itu penelitian yang akan datang dapat difokuskan pada pembuatan model kebijakan pengelolaan dana desa, sehingga nantinya dapat diciptakan standar kinerja pengelolaan dana desa.

\section{DAFTAR PUSTAKA}

Akib, M., Nurnaluri, S., dan Sutrawati, K. 2017. Peran Perangkat Desa dalam Akuntabilitas Pengelolaan Dana Desa (Studi Kasus pada Desa Pudaria Kecamatan Mpramo). Jurnal Akuntansi dan Keuangan .

Astuti, T. P., dan Yulianto. 2016. Good Governance Pengelolaan Keuangan Desa Menyongsong Berlakunya Undang-Undang No. 6 Tahun 2014. 
Berkala Akuntansi dan Keuangan Indonesia 1-14.

Atiq, F. 2018. Kampusnesia. Dipetik January 16, 2019, dari Kampusnesia: https:// kampusnesia.com/2018/03/12/pemka b-demak-alokasikan-dana-desa-2018senilai-rp2295-miliar/

Cooper, Donald R. and Pamela S. Schindler. 2013. Business Research Methods, International Edition, McGraw-Hill Companies, Inc. New York

Drama, H. 2014. Pengaruh Penerapan Sistem Akuntansi Keuangan Daerah terhadap Kualitas Informasi Laporan Keuangan dengan Sistem Pengendalian Intern sebagai Variabel Intervening. Thesis. Padang.

Ernawilis. 2015. Pengaruh Akuntabilitas Publik, Partisipasi Penyusunan Anggaran, Kejelasan Sasaran Anggaran dan Struktur Desentralisasi terhadap Kinerja Aparat Pemerintah Daerah SKPD dengan Pengawasan Internal sebagai Variabel Pemoderasi Kabupaten Kuantang Singing. Jom Fekom 114.

Hair JH, Hult GT, Ringle CM, Sarstedt M. 2017. A Primer on Partial Least Square Structural Ecquation Modelling (PLS $S E M)$, Second edition, SAGE Publications, Inc.

Halidayati, I. 2014. Pengaruh Pengawasan Internal, Pengawasan Eksternal dan Implementasi Anggaran Berbasis Kinerja terhadap Kinerja Pemerintah Daerah (Studi Empiris pada Satuan Perangkat Kerja Daerah Kota Payakumbu). Artikle Ilmiah 1-22.

Hamsinar. 2017. Pengaruh Partisipasi Masyarakat, Akuntabilitas dan Transparansi Kebijakan Publik terhadap Kualitas Laporan Keuangan Pemerintah Daerah dengan Sistem Pengendalian Intern sebagai Variabel Moderasi (Studi Kasus Kabupaten Pinrang). Thesis. Universitas Islam Negeri Alaudin. Makassar.

Hidayati, N., dan Dianawati, W. 2017. Pengendalian Internal sebagai Variabel
Moderasi pada Pengaruh Desentralisasi terhadap Kinerja Manajerial. Berkala Akuntansi dan Keuangan Indonesia 54-72.

Indriansari, N. T. 2017. Peran Perangkat desa dalam Akuntabilitas Pengelolaan Keuangan Desa (Studi pada Desa Karangsari Kecamatan Sukodono). Jurnal Ilmiah Ilmu Akuntansi Keuangan dan Pajak (Assets).

Kurniawan, A. 2018. Mediajateng. Dipetik January 16, 2019, dari Mediajateng.net: http:/ / mediajateng.net/2018/06/30/in i-terobosan-pemkab-demak-untukcegah-kebocoran-dana-desa/15911/

Kurniawan, A. 2012. Pengaruh Partisipasi Masyarakat, Transparansi Kebijakan Publik, Akuntabilitas Publik dan Pengetahuan dewan tentang Anggaran terhadap Penyusunan APBD. Thesis. Surakarta.

Mardiasmo. 2009. Akuntansi Sektor Publik. ANDI. Yogyakarta.

Mardiyasari, D. P., dan Supriyadi. 2015. Persepsi Masyarakat Mengenai Kinerja Aparat Pemerintah Desa dalam Pelayanan Publik di Kelurahan Bangunharjo Sewon Bantul. Jurnal Citizenship .

Mocheriono. 2012. Perencanaan, Aplikasi $\mathcal{E}$ Pengembangan Indikator Kinerja Utama Bisnis dan Publik. Rajawali Pers. Jakarta.

Mouallem, L. E., dan Analoui, F. 2014. The Need for Capacity Building in Human Resource Management Related Issues: A Case Study from the Middle East (Lebanon). European Scientific Journal 245-254.

Mulyani, M., Suryono, H., dan Vein, R. 2017. Pengaruh Tingkat Kedisiplinan Aparat Desa terhadap Kualitas Pelayanan pada Masyarakat di Kecamatan Pedan Kabupaten Klaten Tahun 2012. Educitizen .

Munti, F., dan Fahlevi, H. 2017. Determinan Kinerja Pengelolaan Keuangan Desa: Studi pada Kecamatan Gandapura Kabupaten Bireuen Aceh. Jurnal Akuntansi dan Inventasi 172-182.

Pazri, M. 2016. Implementasi Prinsip Good Governance dalam Sistem Pengelolaan 
Keuangan Daerah di Indonesia. Badamai Law Journal 13-16.

Primadana, G. H., Yuniarta, G. A., dan Adiputra, M. P. 2014. Pengaruh Partisipasi dalam Penyusunan Anggaran, Kejelasan Sasaran Anggaran dan Struktur Desentralisasi terhadap Kinerja Manajerial SKPD dengan Pengawasan Internal sebagai Variabel Pemoderasi (Studi Empiris pada Pemerintah Kabupaten Badung). e-Journal S1 Ak Universitas Pendidikan Ghanesha Jurusan Akuntansi Program S1 1-11.

Rafar, T. M., Fahlevi, dan Basri. 2015. Pengaruh Kompetensi Pengelola Keuangan dan Akuntabilitas terhadap Kinerja Pengelolaan Keuangan Daerah. Jurnal Administrasi Akuntansi 125-135.

Rahadian, A. 2008. Mewujudkan Good Governance melalui Pelayanan Publik. Gajah Mada University Press. Yogyakarta.

Rustiarini, N. W. 2016. Good Governance dalam Pengelolaan Dana Desa. Simposium Nasional Akuntansi XIX , 1-18.

Sari, D. 2013. Pengaruh Sistem Pengendalian Intern Pemerintah, Implementasi tandar Akuntansi Pemerintahan, Penyelesaian Temuan Audit Terhadap Penerapan Prinsip-Prinsip Tata Kelola
Pemerintahan Yang Baik. Proceding SNA XVI, :1007.

Sari, I. M., dan Abdullah, F. 2017. Analisis Ekonomi Kebijakan Dana Desa terhadap Kemisikinan Desa di Kabupaten Tulung Agung. Jurnal Ekonomi Pembangunan .

Soleh, A., Fer, S., dan Susanti, R. 2017. Persepsi Aparatur Pemerintah Desa Terhadap Dana Desa di Kecamatan Seluma Barat Kabupaten Seluma. Jurnal Ekombis Review .

Soleh, A., Susanto, F., dan Susanti, R. 2016. Persepsi Aparatur Pemerintah Desa terhadap Dana Desa di Kecamatan Seluma Barat Kabupaten Seluma. Ekombis Review 114-125.

Sugiarti, E., dan Ivan, Y. 2017. Analisis Faktor Kompetensi SDM Pemanfaat Teknologi Informasi dan Partisipasi Penganggaran terhadap akuntabilitas Pengelolaan Dana Desa. SNAB. Universitas Widyatama.

Tarjono, dan Nugraha, A. 2015. Pengaruh Partisipasi Anggaran dan Desentralisasi Organisasi terhadap Kinerja Manajerial dengan Pengawasan Internal sebagai Variabel Pemoderasi (Studi Analisis pada Pemerintah Kabupaten Pemalang). Media Ekonomi Dan Manajemen 85-100. 